\title{
RISALAH|
}

DOI: $10.24014 / j d r . v 31 i 1.10040$

\section{PENGARUH PROMOSI DAN KUALITAS PELAYANAN TERHADAP KEPERCAYAAN DAN LOYALITAS DONATUR DOMPET DHUAFA RIAU}

\author{
Andrika Saputra $^{1 *}$, Alvi Furwanti Alwie ${ }^{2,}$ Any Widayatsari ${ }^{3}$ \\ ${ }^{1,2,3}$ Universitas Riau \\ Email: aandrikaa@gmail.com
}

\begin{abstract}
Keyword
Promotion, service quality, trust, loyality

Abstract

This study aims to analyze the effect of promotion and service quality on the trust and loyalty of donors to perform Zakat, Infaq, and Alms in Dompet Dhuafa Riau. This research uses a quantitative approach with a survey method of 312 donors of Dompet Dhuafa Riau. The variable measurement uses a Likert scale with weights from 1 to 5. To analyze the effect of variables X1, X2 on Z through Y using statistical techniques path analysis. To test the level of significance using the $t$ test. This study found promotion had a positive and significant effect on loyalty, service quality had a positive and significant effect on loyalty, the trust had a positive and significant effect on loyalty, the promotion had an effect on loyalty through trust, and service quality had an effect on loyalty through trust.
\end{abstract}

\author{
Kata Kunci \\ Promosi, kualitas \\ pelayanan, \\ kepercayaan, \\ loyalitas
}

\begin{abstract}
Abstrak
Penelitian ini bertujuan untuk menganalisis pengaruh promosi dan kualitas pelayanan terhadap kepercayaan dan loyalitas donatur untuk menunaikan Zakat, Infak, dan Sedekah (ZIS) di Dompet Dhuafa Riau. Penelitian ini menggunakan pendekatan kuantitatif dengan metode survei terhadap 312 orang donatur Dompet Dhuafa Riau. Pengukuran variabe menggunakan skala Likert dengan bobot dari 1 sampai 5 . Untuk menganalisa pengaruh variabel $\mathrm{X} 1, \mathrm{X} 2$ terhadap $\mathrm{Z}$ melalui $\mathrm{Y}$ menggunakan teknik statistik analisis jalur. Untuk menguji tingkat signifikansi menggunakan uji t. Penelitian ini menemukan promosi berpengaruh positif dan signifikan terhadap loyalitas, kualitas pelayanan berpengaruh positif dan signifikan terhadap loyalitas, kepercayaan berpengaruh positif dan signifikan terhadap loyalitas, promosi berpengaruh terhadap loyalitas melalui kepercayaan, dan kualitas pelayanan berpengaruh terhadap loyalitas melalui kepercayaan.
\end{abstract}

\section{Pendahuluan}

Pengelolaan Zakat di Indonesia diatur dalam Undang-Undang Nomor 23 tahun 2011. Pengelolaan Zakat di Indonesia terbagi menjadi dua sistem yakni pengelolaan zakat oleh lembaga pemerintah dan lembaga masyarakat. Seperti terdapat dalam pasal 5 ayat 1 bahwa untuk melaksanakan pengelolaan zakat, pemerintah membentuk Badan Amil 
Zakat Nasional (BAZNAS). Selain itu, dalam pasal 17, masyarakat dapat membentuk Lembaga Amil Zakat (LAZ) untuk membantu BAZNAS dalam pelaksanaan pengumpulan, pendistribusian, dan pendayagunaan zakat. Adanya undang-undang tersebut maka zakat dianjurkan untuk disalurkan melalui amil zakat dari pada menyalurkannya secara langsung kepada mustahik (penerima zakat).

Melihat potensi zakat yang sangat besar tersebut, LAZ berusaha meningkatkan kemampuan daya saingnya menghimpun dana ZIS dan mempertahankan donatur mereka agar tetap loyal. Saat ini, ada 17 Lembaga Amil Zakat Nasional (LAZNAS) yang aktif dalam melakukan aktifitas penghimpunan dan penyaluran dana zakat, infak, dan sedekah (BAZNAS, 2018). Akibat banyaknya jumlah LAZNAS, menimbulkan persaingan guna meraih, penghimpunan dan penyaluran zakat yang tinggi serta menjaga kesetiaan donaturnya. Agar LAZ berhasil mempertahankan eksistensinya maka harus memperhatikan aktivitas promosi, serta kualitas layanan kepada donatur sehingga donatur percaya dan loyalitas terhadap LAZ tersebut.

Dompet Dhuafa Riau sebagai salah satu LAZ dinilai belum maksimal mempertahankan loyalitas donaturnya. Hal ini dapat terlihat pada retensi donatur yang masih sangat kecil jika dibandingkan dengan jumlah donatur yang bertransaksi setiap tahunnya. Hal tersebut dalam dilihat pada tabel berikut ini:

Tabel 1. Jumlah donatur yang bertransaksi pada LAZ Dompet Dhuafa Riau Tahun 2013-2019

\begin{tabular}{cccc}
\hline Tahun & $\begin{array}{c}\text { Donatur Baru } \\
\text { (Orang) }\end{array}$ & $\begin{array}{c}\text { Donatur Lama } \\
\text { (Orang) }\end{array}$ & $\begin{array}{c}\text { Persentase } \\
\text { Loyal (\%) }\end{array}$ \\
\hline 2013 & 115 & 0 & \\
2014 & 343 & 33 & \\
2015 & 1.505 & 68 & \\
2016 & 1.032 & 157 & \\
2017 & 898 & 288 & \\
2018 & 1.109 & 352 & \\
2019 & 1.138 & 522 & $\mathbf{2 3 \%}$ \\
\hline Total & $\mathbf{6 . 1 4 0}$ & $\mathbf{1 . 4 2 0}$ & \\
\hline
\end{tabular}

Sumber : LAZ Dompet Dhuafa Cabang Riau, 2020

Berdasarkan Tabel 1 di atas, terdapat penambahan donatur baru setiap tahunnya dari tahun 2013 hinga 2019. Namun, untuk penambahan jumlah donatur dari donatur loyal masih rendah. Tahun 2013 hingga 2019 hanya 23 persen donatur loyal di LAZ Dompet Dhuafa Riau. Total 6.140 orang yang pernah menjadi donatur, 1.420 orang donatur yang kembali berdonasi. Hal ini menunjukkan tingkat loyalitas donatur Dompet Dhuafa Riau tergolong masih rendah. Tentunya hal tersebut membuat LAZ Dompet Dhuafa Riau perlu membenahi semua bagian, terutama pelayanan terhadap donatur untuk mempertahankan dan meningkatkan loyalitas donatur (Naufal, 2019). 
Selain itu, kepercayaan konsumen yang tinggi juga membuat konsumen menentukan sikap loyal pada jasa yang digunakan. Lau \& Lee (1999) mengatakan kepercayaan melibatkan kesediaan seseorang untuk berperilaku tertentu karena dia meyakini bahwa mitranya memberikan sesuatu sesuai dengan yang diharapkan. Jumlah capaian dana menjadi salah satu indikator kepercayaan donatur terhadap Lembaga Amil Zakat tersebut. Venable et al. (2005) mengungkapkan bahwa kepercayaan berperan penting dalam keputusan donatur apakah akan mendonasikan uang, waktu, barang atau jasa pada organisasi tersebut. Capain penghimpunan Dompet Dhuafa Riau dapat dilihat pada tabel 2 berikut ini:

Tabel 2. Total Penghimpunan ZIS Dompet Dhuafa Riau Tahun 2013-2019

\begin{tabular}{|c|c|c|c|c|}
\hline Tahun & Jenis Donasi & $\begin{array}{c}\text { Jumlah } \\
\text { (Rupiah) }\end{array}$ & $\begin{array}{l}\text { Total Donasi } \\
\text { (Rupiah) }\end{array}$ & $\begin{array}{c}\text { Pertumbuhan } \\
\text { Donasi }\end{array}$ \\
\hline \multirow{2}{*}{2013} & Zakat & 75.734 .000 & \multirow{2}{*}{106.242 .500} & \multirow{2}{*}{$0 \%$} \\
\hline & Infak / Sedekah & 30.508 .500 & & \\
\hline \multirow{2}{*}{2014} & Zakat & 123.586 .496 & \multirow{2}{*}{253.584 .043} & \multirow{2}{*}{$139 \%$} \\
\hline & Infak / Sedekah & 129.997 .547 & & \\
\hline \multirow{2}{*}{2015} & Zakat & 289.316 .733 & \multirow{2}{*}{874.868 .384} & \multirow{2}{*}{$245 \%$} \\
\hline & Infak / Sedekah & 585.551 .651 & & \\
\hline \multirow{2}{*}{2016} & Zakat & 486.921 .434 & \multirow{2}{*}{1.318 .244 .886} & \multirow{2}{*}{$51 \%$} \\
\hline & Infak / Sedekah & 831.323 .452 & & \\
\hline \multirow{2}{*}{2017} & Zakat & 552.469 .006 & \multirow{2}{*}{ 2.502.997.007 } & \multirow{2}{*}{$90 \%$} \\
\hline & Infak / Sedekah & 1.950 .528 .001 & & \\
\hline \multirow{2}{*}{2018} & Zakat & 1.010 .372 .720 & \multirow{2}{*}{ 4.194.345.354 } & \multirow{2}{*}{$68 \%$} \\
\hline & Infak / Sedekah & 3.183 .972 .634 & & \\
\hline \multirow{2}{*}{2019} & Zakat & 1.070 .188 .410 & \multirow{2}{*}{4.250 .669 .916} & \multirow{2}{*}{$1 \%$} \\
\hline & Infak / Sedekah & 3.180 .481 .506 & & \\
\hline
\end{tabular}

Sumber : LAZ Dompet Dhuafa Cabang Riau, 2020

Berdasarkan Tabel 2 di atas, dapat disimpulkan bahwa kinerja penghimpunan dana ZIS pada LAZ Dompet Dhuafa Riau mengalami peningkatan setiap tahunnya sejak tahun 2013-2019. Meskipun terjadi peningkatan penghimpunan zakat dan infak/sedekah pada LAZ Dompet Dhuafa Riau, akan tetapi masih terdapat kesenjangan yang sangat tinggi antara potensi dan aktualisasi penghimpunan zakat tersebut. Potensi ZIS di Provinsi Riau menurut Badan Amil Zakat Nasional (BAZNAS) mencapai 6,7 triliun rupiah.

Faktor lain yang dapat mempengaruhi loyalitas donatur adalah aktifitas promosi yang dilakukan organisasi. Menurut Lupiyoadi (2009) promosi merupakan salah satu variabel dalam bauran pemasaran yang sangat penting dilaksanakan oleh perusahaan dalam memasarkan produk jasa. Hurriyati (2010) mengemukakan bahwa promosi merupakan suatu bentuk aktivitas pemasaran yang berusaha menyebarkan informasi, 
mempengaruhi atau membujuk, dan mengingatkan pasar atas perusahaan dan produknya agar bersedia menerima, membeli, dan loyal pada produk yang ditawarkan perusahaan yang bersangkutan. Selain kualitas layanan, promosi menjadi penarik minat donatur dalam memilih LAZ. Menurut Asnawi (2017) dalam Islam promosi merupakan upaya untuk memperkenalkan dan menawarkan produk kepada konsumen, kegiatan yang dilakukan dilarang memberikan informasi yang berlebihan. Promosi yang biasanya dilakukan oleh lembaga amil zakat ialah kampanye pentingnya menunaikan zakat infaq dan sedekah dalam Islam.

Fenomena yang terjadi pada LAZ Dompet Dhuafa Riau, peneliti berpendapat bahwa aktivitas promosi yang dilakukan masih lemah, karena hanya terbatas pada penggunaan media konvensional seperti bilboard, spanduk, dan flayer, belum maksimal dalam memanfaatkan periklanan di media massa seperti TV, Radio, Koran, Media Sosial, dan lain-lain. Promosi ini penting untuk dilakukan, karena saat ini masih banyak masyarakat yang belum menunaikan ZIS nya melalui lembaga resmi seperti Dompet Dhuafa Riau. Saat ini masih banyak masyarakat yang menyalurkan secara langsung. Hal ini terjadi dikarenakan kurangnya informasi yang mereka dapatkan (Zaenal, 2018).

Faktor lain yang mempengaruhi loyalitas donatur adalah kualitas pelayanan. Parasuraman dkk, (1988) mendefinisikan kualitas pelayanan sebagai bentuk penilaian konsumen terhadap tingkat layanan yang diterima (Perceived Service) dengan tingkat layanan yang diharapkan (Expected Service). Hal yang sama juga ditegaskan Lupiyoadi (2009) mendefenisikan kualitas pelayan sebagai upaya pemenuhan kebutuhan dan keinginan konsumen serta ketepatan penyampaiannya dalam mengimbangi harapan Konsumen. Pelayanan yang baik serta kenyamanan yang diberikan kepada donatur dapat menentukan laju pertumbuhan suatu lembaga amil zakat. Guna mencapai peningkatan dana ZIS, lembaga zakat kini bersaing dalam melayani donatur.

Berdasarkan hasil pengamatan tentang kualitas pelayanan yang dilakukan oleh LAZ Dompet Dhuafa Riau, maka diperoleh fenomana seperti keterlambatan pengiriman laporan kepada donatur, petugas jemput donasi yang tidak tepat waktu, tidak tersedianya layanan kursi tunggu, dan kurangnya area parkir kendaraan. Hal ini sesuai dengan hasil penelitian yang dilakukan oleh Sutomo (2017) bahwa kualitas pelayanan berpengaruh terhadap kepuasan muzaki, dan kualitas pelayanan berpengaruh terhadap loyalitas muzzaki. Hal serupa juga sesuai dengan hasil penelitian yang dilakukan oleh Kamarudin (2015), kualitas pelayanan berpengaruh secara tidak langsung terhadap loyalitas muzzaki dalam berzakat profesi.

Hasil penelitian yang dilakukan Haryoko (2019) juga mengatakan ada pengaruh yang signifikan antara kualitas pelayanan terhadap loyalitas donatur pada Yayasan Sahabat Yatim Indonesia Cabang Graha Raya Bintaro. Namun berbeda dengan hasil penelitian yang dilakukan Musqari (2018) bahwa tidak terdapat pengaruh antara kualitas pelayanan terhadap loyalitas muzzaki. Nilai yang tidak berpengaruh signifikan ini menunjukkan bahwa semakin baiknya kualitas pelayanan yang diberikan oleh LAZ, belum tentu bisa membuat donatur menjadi loyal kepada LAZ tersebut. Selain itu, 
penelitian Rosidi (2019) menjelaskan bahwa aktifitas promosi dengan pendekatan dakwah dapat dilakukan dengan cara diskusi, penggunaan media radio, serta penggunaan media cetak seperti brosur dan spanduk.

Berdasarkan fenomena tersebut diperoleh gambaran bahwa pemberian kualitas pelayanan jasa yang tidak sesuai dengan keinginan donatur dapat berpengaruh pada semakin berkurangnya donatur, karena akan menciptakan ketidakpuasan yang berdampak pada loyalitas. Penelitian ini bertujuan untuk menganalisis pengaruh promosi dan kualitas pelayanan terhadap kepercayaan dan loyalitas donatur untuk menunaikan Zakat, Infak, dan Sedekah (ZIS) di Dompet Dhuafa Riau.

\section{Metode}

Penelitian ini menggunakan pendekatan kuantitatif dengan metode survei. Menurut Umar (2009) jenis data yang digunakan dalam penelitian ini ada dua jenis data, yaitu : 1) Data primer, yaitu data yang diperoleh langsung dari sumber pertama baik dari individu atau perseorangan seperti hasil pengisian kuisioner yang dilakukan oleh peneliti dan mewawancarai pihak-pihak terkait, serta data lain yang berhubungan dengan masalah penelitian. 2) Data Sekunder, yaitu data yang telah diolah dan telah tersaji serta telah terdokumentasi. Dimana datanya berupa data jumlah donatur, data jumlah penghimpunan ZIS, dan data lain yang relevan dengan penelitian ini.

Teknik pengumpulan data yang digunakan pada penelitian ini adalah: 1) Observasi, pengamatan secara langsung. Instrumen yang dipakai dapat berupa lembar pengamatan, panduan pengamatan, dan lainnya. 2) Kuesioner (Questionnaire), wirawan (2007) mengemukakan bahwa kuesioner adalah sejumlah pernyataan tertulis yang digunakan untuk memperoleh informasi dari responden. Kuesioner digunakan untuk menjaring data kuantitatif. Teknik ini dilakukan dengan cara membagikan kuesioner kepada responden penelitian.

Dalam penelitian ini, populasi yang diambil adalah semua jumlah donatur loyal pada LAZ Dompet Dhuafa Riau yang berjumlah 1.420 orang. Besar ukuran sampel dalam penelitian ini ditentukan dengan rumus Slovin dalam Umar (2009), yaitu:

$$
n=\frac{N}{1+N e^{2}}
$$

Dimana:

$\mathrm{n}=$ Jumlah Sampel

$\mathrm{N}=$ Ukuran Populasi

$\mathrm{e}=$ Persen kelonggaran ketidaktelitian karena kesalahan pengambilan sampel yang masih dapat ditolerir atau diinginkan.

Dengan besar populasi 1.420 orang dan kelonggaran penelitian sebesar 5\% maka jumlah sampel yang akan diambil adalah sebagai berikut :

$$
\frac{N}{1+N e^{2}}
$$




$$
\begin{gathered}
n=\frac{1.420}{1+1.420(0,05)^{2}} \\
n=\frac{1.420}{4,55} \\
n=312
\end{gathered}
$$

Sampel yang diperoleh dengan rumus Slovin adalah 312 orang. Metode yang digunakan adalah simple random sampling, yaitu pengambilan sampel dari anggota populasi yang dilakukan secara acak tanpa memperhatikan strata yang ada dalam populasi itu. Pengujian instrument penelitian yaitu: Pertama, validitas. Menurut Sugiyono (2014), hasil penelitian yang valid bila terdapat kesamaan antara data yang terkumpul dengan data yang sesungguhnya terjadi pada objek yang diteliti. Valid tidaknya suatu item instrumen dapat diketahui dengan membandingkan indeks korelasi product moment Pearson dengan level signifikansi 5\% dengan nilai kritisnya. Menurut Basuki dan Prawoto (2016) agar penelitian lebih teliti, sebuah item sebaiknya memiliki korelasi (r) dengan skor total masing-masing variabel $>0,25$. Item $r$ hitung $<0,25$ akan disingkirkan akibat mereka tidak melakukan pengukuran secara sama dengan yang dimaksud oleh skor total skala dan lebih jauh lagi, tidak memiliki kontribusi dengan pengukuran seseorang jika bukan malah mengacaukan.

Kedua, uji reliabilitas. Reliabilitas adalah indeks yang menunjukan suatu alat pengukur dapat dipercaya atau diandalkan. Bila suatu alat pengukur dipakai dua kali atau lebih untuk mengukur gejala yang sama dan hasil yang diperoleh relatif konsisten maka alat pengukur tersebut reliable. Uji reliabilitas bertujuan untuk mengukur konsisten tidaknya jawaban seseorang terhadap item-item pernyataan didalam kuesioner (Sekaran, 2006). Menurut Basuki \& Prawoto (2016) uji reliabilitas dilakukan dengan tujuan untuk mengukur konsistensi internal angket dengan menggunakan Cronbach's Alfa dengan syarat nilai Cronbach's Alpha di atas 0,6.

Untuk dapat dilakukan analisis pada analisis jalur, maka sebelum melakukan analisis, syarat untuk analisis tersebut perlu diuji dahulu asumsi klasiknya yaitu: Pertama, uji normalitas. Uji normalitas menjadi hal penting karena salah satu syarat pengujian parametric-test (uji parametrik) adalah data harus memiliki distribusi normal (atau berdistribusi normal). Adapun kriteria pengujiannya adalah sebagai berikut: angka signifikansi uji Kolmogorov-Smirnov Sig. > 0,05 menunjukan data berdistribusi normal dan angka signifikansi uji Kolmogorov-Smirnov Sig. $<0,05$ menunjukan data tidak berdistribusi normal.

Kedua, uji multikolinieritas. Menurut Gujarati (2012) uji multikolinearitas adalah pengujian untuk mengetahui ada atau tidaknya hubungan linear secara sempurna antar variabel independen dengan model regresi. Indikator multikolinearitas adalah VIF (Variance Inflation Factor). Semakin tinggi nilai VIF maka nilai multikolinearitas antara variabel dependennya semakin tinggi. Metode untuk menguji adanya multikolinearitas dilihat dari nilai toleransi value atau Variance Inflation Factor (VIF). Apabila nilai VIF 
variabel independen dibawah nilai 10 dan tolerance value diatas 0,10. Maka dapat disimpulkan bahwa tidak terjadi multikolinearitas dalam model regresi sehingga model tersebut reliable sebagai dasar analisis.

Ketiga, uji heterokedastisitas. Menurut Ghozali (2011) model regresi yang baik adalah homokedastisitas atau tidak terjadi heteroskedastisitas. Heterokedastisitas berarti variasi (varians) variabel tidak sama untuk semua pengamatan. Deteksi ada tidaknya problem heteroskedastisitas adalah dengan media grafik, apabila grafik membentuk pola khusus maka model terdapat heteroskedastisitas. Dasar pengambilan keputusan : jika ada pola tertentu, seperti titik-titik (point-point) yang ada membentuk suatu pola tertentu yang teratur (bergelombang, melebar kemudian menyempit), maka telah terjadi Heteroskedastisitas dan jika tidak ada pola yang jelas, serta titik-titik menyebar di atas dan di bawah angka 0 pada sumbu Y, maka tidak terjadi Heteroskedastisitas.

Analisis data dalam penelitian ini yaitu dengan menggunakan analisis jalur (path analisys). Ghozali (2011) mengemukakan analisis jalur (path analysis) merupakan perluasan dari analisis regresi linear berganda, atau analisis jalur adalah penggunaan analisis regresi untuk menaksir hubungan kausalitas antara variabel (model casual) yang telah ditetapkan sebelumnya berdasarkan teori. Analisis jalur (path analysis) digunakan untuk menguji pengaruh variabel intervening. Yang dapat dilakukan oleh analisis jalur adalah menentukan pola hubungan antara tiga atau lebih variabel dan tidak dapat digunakan untuk mengkonfirmasi atau menolak hipotesis kausalitas imajiner.

Untuk menentukan hipotesis di terima atau tidak dapat diliat dengan uji hipotesis yaitu: 1) Koefisien Determinasi $\left(R^{2}\right)$, besarnya koefisien determinasi $\left(R^{2}\right)$ terhadap variabel bebas. Syarat koefisien determinasi $\left(\mathrm{R}^{2}\right)$ dikatakan kuat atau lemah yaitu apabila $\left(\mathrm{R}^{2}\right)$ mendekati angka 1, maka berarti pengaruh variabel bebas secara simultan dianggap kuat dan apabila $\left(\mathrm{R}^{2}\right)$ mendekati nol (0) maka pengaruh variabel bebas terhadap variabel terikat secara simultan adalah lemah; dan 2) Uji t, untuk menguji signifikansi Pengaruh Promosi dan Kualitas Pelayanan Secara Parsial terhadap Kepercayaan dan Loayalitas Donatur pada LAZ Dompet Dhuafa Riau digunakan uji t. Jika t hitung lebih besar dari pada $t$ tabel ( $t_{\text {hitung }}>t_{\text {tabel }}$ ) hal ini menunjukan bahwa variabel bebas mempunyai pengaruh yang signifikan terhadap variabel terikat dan jika t hitung lebih kecil dari pada tabel $\left(t_{\text {hitung }}<t_{\text {tabel }}\right)$ hal ini menunjukan bahwa variabel bebas tidak mempunyai pengaruh yang signifikan terhadap variabel terikat.

\section{Hasil dan Pembahasan \\ Uji Validitas}

Pada uji validitas, sampel yang digunakan sebanyak 312 responden. Menurut Basuki \& Prawoto (2016) agar penelitian lebih teliti, sebuah item sebaiknya memiliki korelasi ( $r$ ) dengan skor total masing-masing variabel $>0,25$. Nilai $r$ hitung berkisar antara 0,259 sampai 0,573 . Jadi dari hasil pengujian diperoleh bahwa nilai $r$ hitung $\geq$ dari nilai $r$ tabel 0,25 maka dapat disimpulkan bahwa dari keempat variabel yang meliputi, loyalitas, kepercayaan, promosi dan kualitas pelayanan, memiliki nilai korelasi yang lebih besar 
dari $r$ tabel. Berdasarkan hasil pengujian diatas dapat ditarik kesimpulan bahwa semua item pernyataan dinyatakan valid dan dapat digunakan untuk penelitian.

\section{Uji Reliabilitas}

Berdasarkan hasil uji reliabilitas dapat diketahui hasil pengujian nilai reliabilitas keempat variabel berada di atas angka 0,6. Artinya adalah bahwa alat ukur yang digunakan dalam penelitian ini reliable.

\section{Uji Normalitas}

Hasil uji normalitas menunjukkan bahwa data telah berdistribusi normal. hal ini ditunjukkan dengan hasil uji Kolmogorov-Smirnov yang menunjukkan nilai Asymp Sig (2-tailed) lebih besar dari nilai alpha $=0,05$, yaitu variabel promosi 0,379 , variabel kualitas pelayanan 0,076, variabel kepercayaan 0,065 dan variabel loyalitas 0,089. Sehingga model tersebut telah memenuhi asumsi untuk dipakai sebagai persamaan Path Analysis.

\section{Uji Multikolinearitas}

Dari hasil perhitungan analisis data diperoleh nilai VIF pada kedua model $<10$ dan tolerance $>0,10$. Hal ini dapat disimpulkan bahwa kedua model tersebut bebas dari multikolinearitas.

\section{Uji Heterokedatisitas}

Dari hasil perhitungan analsisi data terlihat bahwa titik-titik menyebar secara acak diatas dan dibawah angka 0 pada sumbu Y. Dapat diartikan bahwa dua model tersebut tidak terdapat heterokedastisitas.

\section{Koefisien Determinasi $\left(R^{2}\right)$}

1. Koefisien determinasi sub struktur 1

Hasil uji koefisien determinasi sub struktur 1 dalam penelitian dengan nilai sebesar 0,781 atau $78,1 \%$ dan nilai $\mathrm{e}_{1}=0,219(\sqrt{1}-0,781)$ yang bermakna promosi dan kualitas pelayanan secara bersama-sama dapat memberikan pengaruh terhadap variabel kepercayaan sebesar $78,1 \%$.

\section{Koefisien determinasi sub struktur 2}

Hasil uji koefisien determinasi sub struktur 2 dalam penelitian dapat dilihat pada nilai sebesar 0,889 atau $88,9 \%$ dan nilai $\mathrm{e}_{2}=0,111(\sqrt{1}-0,889)$ yang bermakna promosi, kualitas pelayanan dan kepercayaan secara bersama-sama dapat memberikan pengaruh terhadap variabel loyalitas sebesar $88,9 \%$.

\section{Analisis Jalur}

Setelah nilai masing-masing variabel laten datanya diperoleh, maka dilakukan analisis jalur. Analisis jalur pada penelitian ini memiliki 2 persamaan structural sesuai 
dengan yang telah dikemukakan pada bab sebelumnya. Adapun hasil regresi dari persamaan tersebut dapat dilihat sebagai berikut:

\section{Uji Persamaan Substruktur 1}

Pengaruh langsung variabel promosi dan kualitas pelayanan terhadap kepercayaan dapat dilihat pada tabel 4.15 sebagai berikut:

Tabel 3. Hasil Uji Promosi dan Kualitas Pelayanan Terhadap Kepercayaan Coefficients $^{\mathrm{a}}$

\begin{tabular}{|c|c|c|c|c|c|c|}
\hline \multirow{2}{*}{\multicolumn{2}{|c|}{ Model }} & \multicolumn{2}{|c|}{$\begin{array}{l}\text { Unstandardized } \\
\text { Coefficients }\end{array}$} & \multirow{2}{*}{$\begin{array}{c}\text { Standardized } \\
\text { Coefficients } \\
\text { Beta }\end{array}$} & \multirow[t]{2}{*}{$\mathbf{T}$} & \multirow[t]{2}{*}{ Sig. } \\
\hline & & B & Std. Error & & & \\
\hline \multirow{4}{*}{1} & (Constant) & 1.003 & .446 & & 2.248 & .025 \\
\hline & Promosi & .380 & .030 & .509 & 12.548 & .000 \\
\hline & Kualitas & .348 & .033 & .434 & 10.695 & .000 \\
\hline & Pelayanan & & & & & \\
\hline
\end{tabular}

a. Dependent Variable: Kepercayaan

Sumber : Data Olahan Hasil Penelitian, 2020

Berdasarkan Tabel 3 di atas dapat digambarkan persamaan struktural 1 sebagai berikut:

$$
\mathrm{Y}=0,509 \mathrm{X}_{1}-0,434 \mathrm{X}_{2}+\mathrm{e}
$$

\section{Uji Persamaan Substruktur 2}

Pengaruh langsung promosi, kualitas pelayanan dan kepercayaan terhadap loyalitas dapat dilihat pada tabel 4 sebagai berikut:

Tabel 4. Pengaruh promosi, kualitas pelayanan dan kepercayaan terhadap loyalitas Coefficients $^{\mathrm{a}}$

\begin{tabular}{|c|c|c|c|c|c|c|}
\hline \multirow{2}{*}{\multicolumn{2}{|c|}{ Model }} & \multicolumn{2}{|c|}{$\begin{array}{l}\text { Unstandardized } \\
\text { Coefficients }\end{array}$} & \multirow{2}{*}{$\begin{array}{c}\text { Standardized } \\
\text { Coefficients } \\
\text { Beta }\end{array}$} & \multirow[t]{2}{*}{$\mathbf{T}$} & \multirow[t]{2}{*}{ Sig. } \\
\hline & & B & Std. Error & & & \\
\hline \multirow{4}{*}{1} & (Constant) & -1.072 & .341 & & -3.141 & .002 \\
\hline & Promosi & .106 & .028 & 133 & 3.747 & .000 \\
\hline & Kualitas Pelayanan & .341 & .029 & .399 & 11.807 & .000 \\
\hline & Kepercayaan & .502 & .043 & .470 & 11.633 & .000 \\
\hline
\end{tabular}

a. Dependent Variable: Loyalitas

Sumber : Data Olahan Hasil Penelitian, 2020

Berdasarkan tabel 4 diatas dapat digambarkan persamaan struktural 2 sebagai berikut: 


$$
Z=-0,133 X_{1}+-0,399 X_{2}+-0,470 Y+e
$$

Berdasarkan hasil pengujian persamaan struktural 1 dan 2 diperoleh diagram jalur empiris model loyalitas :

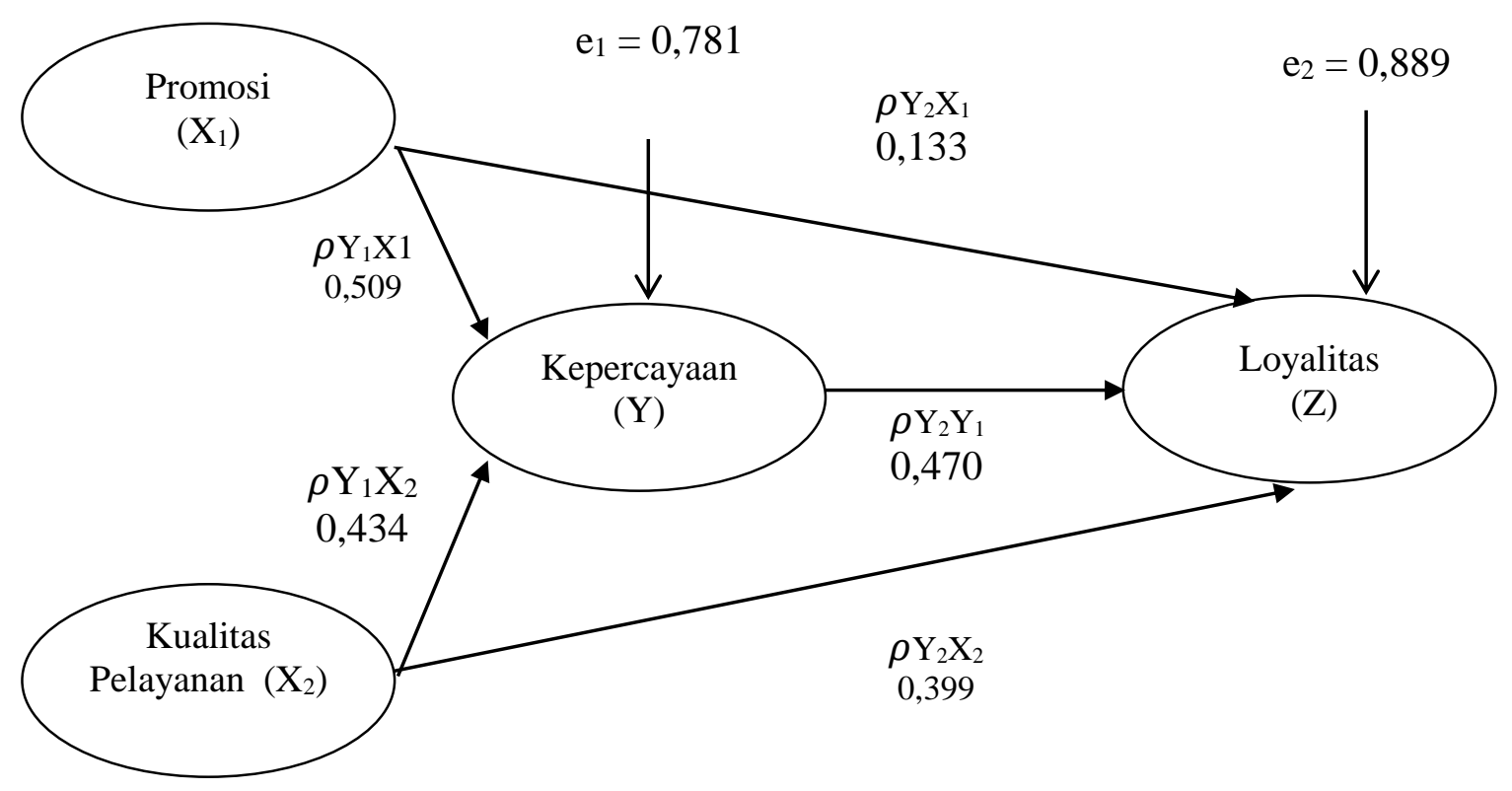

Sumber : Data Olahan Hasil Penelitian, 2020

Gambar 1. Diagram jalur hasil analisis pengaruh promosi dan kualitas pelayanan terhadap loyalitas langsung dan tidak langsung melalui variabel kepercayaan

Tujuan analisis jalur adalah memperhitungkan pengaruh langsung dan tidak langsung, berdasarkan tabel 3 dan 4 diatas dapat ditarik kesimpulan analisis secara menyeluruh sebagai berikut ini :

Tabel 5. Pengujian Hipotesis Pengaruh Langsung

\begin{tabular}{cllccc}
\hline No & \multicolumn{1}{c}{$\begin{array}{c}\text { Variabel } \\
\text { Independen }\end{array}$} & $\begin{array}{c}\text { Variabel } \\
\text { Dependen }\end{array}$ & $\begin{array}{c}\text { Koefisien } \\
\text { Jalur }\end{array}$ & P Value & Keterangan \\
\hline 1 & Promosi & Loyalitas & 0,133 & 0,000 & Signifikan \\
2 & Kualitas Pelayanan & Loyalitas & 0,399 & 0,000 & Signifikan \\
3 & Kepercayaan & Loyalitas & 0,470 & 0,000 & Signifikan \\
4 & Promosi & Kepercayaan & 0,509 & 0,000 & Signifikan \\
5 & Kualitas Pelayanan & Kepercayaan & 0,434 & 0,000 & Signifikan \\
\hline
\end{tabular}

Sumber : Data Olahan Hasil Penelitian, 2020

Pengaruh langsung dan tidak langsung promosi dan kualitas pelayanan terhadap loyalitas yang dimediasi oleh kepercayaan dapat dilihat pada tabel 6 sebagai berikut.

Tabel 6. Ringkasan Hasil Pengujian Hipotesis 


\begin{tabular}{|c|c|c|c|c|c|}
\hline \multirow{3}{*}{$\begin{array}{l}\text { Pengaruh Antar } \\
\text { Variabel }\end{array}$} & \multirow{3}{*}{$\begin{array}{l}\text { Koefisien } \\
\text { Jalur }\end{array}$} & \multicolumn{2}{|c|}{ Pengaruh \% } & \multirow{3}{*}{ t-hitung } & \multirow{3}{*}{ R square } \\
\hline & & & Tidak & & \\
\hline & & Langsung & Langsung & & \\
\hline $\mathbf{X 1} \rightarrow \mathrm{Y}$ & 0,509 & $25,90 \%$ & & 12,548 & \multirow{2}{*}{0.781} \\
\hline $\mathbf{X} 2 \rightarrow \mathrm{Y}$ & 0,434 & $18,83 \%$ & & 10,695 & \\
\hline $\mathrm{X} 1 \rightarrow Z$ & 0,133 & $1,77 \%$ & - & 3,747 & \multirow{3}{*}{0,889} \\
\hline $\mathrm{X} 2 \rightarrow \mathrm{Z}$ & 0,399 & $15,92 \%$ & - & $11,, 807$ & \\
\hline $\mathbf{Y} \rightarrow \mathbf{Y Z}$ & 0,470 & $22,09 \%$ & - & 11,633 & \\
\hline $\mathrm{X} 1 \rightarrow \mathrm{Y} \rightarrow \mathrm{Z}$ & 0,239 & - & $5,7 \%$ & 3,747 & \\
\hline $\mathrm{X} 2 \rightarrow \mathrm{Y} 1 \rightarrow \mathrm{Y} 2$ & 0,204 & - & $4,16 \%$ & $11,, 807$ & \\
\hline
\end{tabular}

Sumber: Data Olahan Hasil Penelitian, 2020

Berdasarkan tabel 6 di atas menunjukkan bahwa pengaruh langsung dan pengaruh tidak langsung mempunyai pengaruh yang signifikan karena $t_{\text {hitung }}>t_{\text {tabel }}$.

\section{Pembahasan}

Selanjutnya akan dibahas satu per satu pengaruh langsung dan tidak langsung promosi dan kualitas pelayanan terhadap loyalitas melalui peranan kepercayaan, sebagai berikut ini:

\section{Pengaruh Promosi terhadap Loyalitas}

Berdasarkan hasil penelitian menyatakan bahwa promosi berpengaruh positif dan signifikan terhadap loyalitas donatur untuk menunaikan zakat, infak dan sedekah di Dompet Dhuafa Riau. Hal ini menunjukkan promosi mampu memberikan pengaruh secara signifikan terhadap loyalitas donatur, artinya dengan samakin baik sistem promosi yang diberikan LAZ Dompet Dhuafa Riau mampu meningkatkan loyalitas donatur. Oleh sebab itu organisasi harus mampu melakukan promosi lebih baik lagi agar para loyalitas donatur semakin tinggi.

Namun jika dilihat dari hasil rekapitulasi tanggapan responden terhadap variabel promosi berada pada kategori baik. Pernyataan yang mendapat poin tertinggi adalah karyawan Dompet Dhuafa Riau memperkenalkan jasa penghimpunan dan penyaluran zakat, infak, dan sedekah. Artinya LAZ Dompet Dhuafa Riau selalu melakukan kegiatan promosi guna menciptakan kesadaran para donatur untuk menunaikan zakat. Selanjutnya untuk pernyataan dengan skor terendah adalah iklan Dompet Dhuafa Riau di media massa seperti koran, TV, Radio, Media Sosial, dsb dalam hal mengajak menunaikan zakat, infak, dan sedekah. Artinya masih ada beberapa donatur yang merasa bahwa iklan yang di lakukan LAZ Dompet Dhuafa Riau tidak optimal, hal ini dikarenakan masih ada donatur yang kurang jelas dengan iklan yang dilakukan Dompet Dhuafa Riau.

Dari penjelasan di atas dapat diketahui bahwa banyak dari donatur menunaikan zakat di Dompet Dhuafa Riau dikarenakan jelasnya karyawan dalam memperkelankan jasa penghimpunan dan penyaluran zakat, oleh sebab itu masih ada beberapa donatur yang 
merasa bahwa iklan yang dilakukan Dompet Dhuafa Riau tidak efektif di karenakan mereka tidak dapat berinteraksi untuk menanyakan tentang zakat secara jelas. Hasil penelitian ini sejalan dengan penelitian Effendy (2017), Setyaningsi (2013) yang menyatakan bahwa promosi berpengaruh terhadap loyalitas.

\section{Pengaruh Kualitas Pelayanan terhadap Loyalitas}

Berdasarkan hasil penelitian menyatakan bahwa kualitas pelayanan berpengaruh positif dan signifikan terhadap loyalitas donatur untuk menunaikan zakat, infak dan sedekah di Dompet Dhuafa Riau. Hal ini menunjukkan bahwa kualitas pelayanan mampu memberikan pengaruh secara signifikan terhadap loyalitas donator. Artinya dengan samakin baik kualitas pelayanan yang diberikan LAZ Dompet Dhuafa Riau maka akan mampu meningkatkan loyalitas donatur.

Jika dilihat dari hasil rekapitulasi responden kualitas pelayanan berada pada kategori baik. Pernyataan yang mendapat poin tertinggi adalah karyawan Dompet Dhuafa Riau memiliki pengetahuan dalam memberikan informasi. Artinya banyak donatur merasa bahwa karyawan Dompet Dhuafa Riau memiliki pengatahuan yang baik dalam menjelaskan informasi tentang zakat, infak dan sedekah. Selanjutnya untuk pernyataan dengan skor terendah adalah karyawan Dompet Dhuafa Riau memberikan pelayanan yang memuaskan dan sesuai dengan harapan. Artinya masih ada donatur yang merasa bahwa karyawan Dompet Dhuafa Riau yang belum mampu memberikan palayanan sesuai dengan harapan mereka.

Dari penjelasan di atas dapat diketahui bahwa mayoritas donatur merasa bahwa karyawan Dompet Dhuafa Riau memiliki kemampuan untuk memberikan informasi tentang zakat, infak dan sedekah. Namun demikian masih ada juga penilaian donatur yang merasa bahwa karyawan belum mampu memberikan pelayanan sesuai harapan mereka. Hasil penelitian ini, sejalan dengan penelitian Sutomo (2017), Effendy (2017), Setyaningsi (2013), yang menyatakan bahwa kualitas pelayanan berpengaruh terhadap loyalitas, namun tidak sejalan dengan penelitian Safitri (2019), Musqari (2018) yang menyatakan bahwa kualitas pelayanan tidak berpengaruh terhadap loyalitas.

\section{Pengaruh Kepercayaan terhadap Loyalitas}

Berdasarkan hasil penelitian menyatakan bahwa kepercayaan berpengaruh positif dan signifikan terhadap loyalitas donatur menunaikan zakat, infak dan sedekah di LAZ Dompet Dhuafa Riau. Hal ini menunjukkan bahwa kepercayaan mampu memberikan pengaruh secara signifikan terhadap loyalitas. Artinya samakin tinggi tingkat kepercayaan yang dimiliki donatur maka akan mampu meningkatkan loyalitas.

Namun jika dilihat dari hasil rekapitulasi tanggapan responden, kepercayaan berada pada kategori tinggi. Pernyataan yang mendapat poin tertinggi tentang kepercayaan terhadap karyawan Dompet Dhuafa Riau amanah dan dapat dipercaya. Artinya para donatur mayoritas sangat percaya dengan karyawan LAZ Dompet Dhuafa Riau. Hal ini dikarenakan karyawan sangat amanah dengan tanggung jawab yang telah diberikan 
lembaga. Selanjutnya untuk pernyataan dengan skor terendah adalah tentang pelayanan yang sesuai dengan harapan donator. Artinya masih ada donatur yang merasa LAZ Dompet Dhuafa Riau balum mampu memberikan pelayanan sesuai dengan harapan mereka.

Dari penjelasan di atas dapat diketahui bahwa meskipun para donatur percaya kepada karyawan namun masih ada beberapa donatur yang merasa pelayanan dompet dhuafa belum sesuai dengan harapan mereka. Hasil temuan ini, sejalan dengan penelitian Safitri (2019), yang menyatakan bahwa kepercayaan berpengaruh terhadap loyalitas.

\section{Pengaruh Promosi terhadap Loyalitas Melalui Kepercayaan}

Berdasarkan hasil penelitian membuktikan bahwa promosi berpengaruh positif dan signifikan terhadap loyalitas melalui kepercayaan. Hal ini menunjukkan bahwa kepercayaan mampu memediasai pengaruh promosi terhadap loyalitas. Oleh sebab itu organisasi harus mampu meningkatkan promosi dari setiap bulannya sehingga donatur semakin loyal untuk menunaikan zakat, infak dan sedekah di LAZ Dompet Dhuafa Riau. Hal ini sejalan dengan penelitian yang dilakukan Setyaningsih (2013), yang menyatakan bahwa promosi berpengauh terhadap loyalitas yang dimediasi oleh kepercayaan.

\section{Pengaruh Kualitas Pelayanan terhadap Loyalitas Melalui Kepercayaan}

Berdasarkan hasil penelitian membuktikan bahwa kualitas pelayanan berpengaruh positif dan signifikan terhadap loyalitas melalui kepercayaan. Hal ini menunjukkan bahwa kepercayaan mampu memediasai pengaruh kualitas pelayanan terhadap loyalitas. Dengan demikian baiknya kualitas pelayanan yang diberikan organisasi atau lembaga kepada para pelanggannya maka akan mampu berdampak terhadap meningkatkan loyalitas. Hal ini sejalan dengan penelitian yang dilakukan Safitri (2019) yang menyatakan bahwa kualitas pelayanan berpengaruh positif dan signifikan terhadap loyalitas yang dimediasi oleh kepercayaan. Apabila kualitas pelayanan yang diberikan oleh lembaga sangat baik maka kepercayaan muzaki juga akan meningkat sehingga akan mempengaruhi pada loyalitas donatur yang akan mengalami peningkatan pula.

\section{Simpulan}

Berdasarkan dari hasil penelitian yang telah dilakukan, maka disimpulkan bahwa: Pertama, promosi berpengaruh positif dan signifikan terhadap loyalitas. Artinya semakin baik promosi yang dilakukan sebuah lembaga amil zakat maka akan meningkatkan loyalitas donatur. Kedua, bahwa kualitas pelayanan berpengaruh positif dan signifikan terhadap loyalitas. Artinya semakin baik kualitas pelayanan yang dimiliki lembaga amil zakat maka akan meningkatkan loyalitas donatur. Ketiga, kepercayaan berpengaruh positif dan signifikan terhadap loyalitas artinya semakin tinggi tingkat kepercayaan donatur maka akan mampu meningkatkan loyalitas. Keempat, bahwa promosi mampu mempengaruhi loyalitas melalui kepercayaan. Artinya semakin baik promosi yang dilakukan lembaga amil zakat diharapkan mampu meningkatkan kepercayaan donatur 
sehingga loyalitas donatur semakin tinggi. Kelima, kualitas pelayanan berpengaruh terhadap loyalitas melalui kepercayaan. Artinya semakin baik kualitas pelayanan yang dilakukan lembaga amil zakat akan mampu meningkatkan kepercayaan sehingga loyalitas donatur semakin tinggi.

\section{Referensi}

Asnawi, N., \& Fanani, M. A. (2017). Pemasaran Syariah: Teori, Filosofi \& Isu-isu Kontemporer. Depok: Raja Grafindo Persada

Basuki, A. T., \& Prawoto, N. (2016). Analisis Regresi Dalam Penelitian Ekonomi \& Bisnis: Dilengkapi Aplikasi SPSS \& EVIEWS. Depok: PT Rajagrafindo Persada.

Effendy, F. H. (2017). Pengaruh Kualitas Pelayanan dan Promosi Terhadap Loyalitas Konsumen (Studi Pada Dealer Motor Honda di Surabaya). Jurnal Ilmu dan Riset Manajemen (JIRM), 6(2).

Firdaus, M., Beik, I. S., Irawan, T., \& Juanda, B. (2012). Economic estimation and determinations of Zakat potential in Indonesia. Jeddah: Islamic Research and Training Institute.

Ghozali. (2011). Desain Penelitian Kuantitatif \& Kualitatif. Yogyakarta: Penerbit Yogya Pratama.

Haryoko, U. B., \& Dina, R. (2019). Pengaruh Kualitas Pelayanan Terhadap Loyalitas Donatur Pada Yayasan Yatim Indonesia Cabang Graha Raya Bintaro. Jurnal Pemasaran Kompetitif, 2(3), 30-42.

Hurriyati, R. (2010). Bauran pemasaran \& loyalitas konsumen. Bandung: Alfabeta.

Husein, U. (2009). Metode Riset Bisnis. Jakarta: PT. Gramedia Pustaka Utama.

Kamaruddin, A. M., Hasid, H. Z., \& Yuningsih, I. (2015). Faktor-Faktor yang Mempengaruhi Keputusan Berzakat Profesi dan Loyalitas Muzzaki terhadap LAZ Rumah Zakat Kota Samarinda. Jurnal Eksekutif, 12(2).

Lau, G. T., \& Lee, S. H. (1999). Consumers' trust in a brand and the link to brand loyalty. Journal of Market-Focused Management, 4(4), 341-370.

Lupiyoadi, H., \& Hamdani, A. (2009). Manajemen Pemasaran Jasa, Edisi Kedua. Jakarta: Penerbit Salemba Empat, 525.

Musqari, N., \& Huda, N. (2018). Pengaruh Kualitas Layanan terhadap Loyalitas Melalui Variabel Kepuasan pada Lembaga Amil Zakat (Studi pada Baituzzakah Pertamina Kantor Pusat). Perisai: Islamic Banking and Finance Journal, 2(1), 34-53.

Naufal Prima Satria. 2019. Pengaruh Kualitas Layanan dan Promosi terhadap Keputusan Donatur membayar ZIS di Surabaya. Jurnal Ekonomi Islam Vol 2 No 3 pp. 64-71

Parasuraman, A., Zeithaml, V. A., \& Berry, L. L. (1988). Servqual: A multiple-item scale for measuring consumer perc. Journal of retailing, 64(1), 12.

Safitri, D., \& Nurkhin, A. (2019). Pengaruh Kualitas Pelayanan Terhadap Loyalitas Muzaki Melalui Kepuasan Muzaki dan Kepercayaan Muzaki. Economic Education Analysis Journal, 8(2), 501-515. 
Setyaningsih, E. D., \& Mufida, E. (2013). Pengaruh Promosi dan Kualitas Layanan Melalui Kepercayaan Terhadap Loyalitas Pengguna Internet Banking Pada Bank Cimb Niaga. SNIT 2013, 1(1), 30-36.

Sugiyono. 2014. Metode Penelitian Kuantitatif dan Kualitatif. Bandung: CV.Alfabeta.

Sutomo, S., Najib, M., \& Djohar, S. (2017). Pengaruh Kualitas Pelayanan Lembaga Amil Zakat (LAZ) Terhadap Kepuasan dan Loyalitas Muzakki (Studi Kasus LAZ PKPU Yogyakarta). Jurnal Aplikasi Bisnis dan Manajemen (JABM), 3(1), 59.

Venable, B. T., Rose, G. M., Bush, V. D., \& Gilbert, F. W. (2005). The role of brand personality in charitable giving: An assessment and validation. Journal of the academy of marketing science, 33(3), 295-312.

Wirawan. 2007. Teori Aplikasi dan Penelitian. Jakarta : Salemba Empat.

Zaenal, M. H. 2018. Outlook Zakat Indonesia 2018. (N. A \& A. DA, Eds.) (1st ed.). Jakarta: Puskas BAZNAS. 